\title{
Distribution and habitats of Corbicula fluminalis africana (Mollusca: Bivalvia) in South Africa
}

\author{
KN de Kock* and CT Wolmarans \\ School of Environmental Sciences and Development, Zoology, North-West University, Potchefstroom Campus, Private Bag X6001, \\ Potchefstroom 2520, South Africa
}

\begin{abstract}
An account is given of the geographical distribution and habitats of the South African representative of the genus Corbicula Mühlfeld 1811, formerly known as C. africana (Krauss, 1848) but currently regarded as conspecific with the Asian clam, C. fluminalis (Müller, 1774). Data pertaining to 390 samples of C. fluminalis africana (Krauss, 1848) were extracted from the database of the National Freshwater Snail Collection (NFSC) and statistically analysed. Details of each habitat, as well as mean altitude and mean annual temperature and rainfall for each locality, were processed to determine chi-square and effect size values. An integrated decision tree constructed from the data indicated that temperature, altitude, current speed and type of water-body seemed the more important factors that significantly influenced the distribution of this species in South Africa. In spite of the fact that $C$. fluminalis africana is relatively widespread in South Africa and was recovered from a wide range of habitat types and water-bodies, it has, to our knowledge, not yet been reported to cause problems in cooling circuits as experienced elsewhere in the world. It is proposed that the feasibility to exploit this species for monitoring heavy metal pollution in freshwater biotopes should be investigated in view of reports from elsewhere in the world that it has the ability to accumulate metals such as copper, lead, zinc and manganese.
\end{abstract}

Keywords: Corbicula fluminalis africana, C. fluminea, geographical distribution, habitat analysis, freshwater Bivalvia, South Africa

\section{Introduction}

The distribution of the bivalve genus Corbicula was reported by Pilsbury and Bequart in 1927 as widespread over the AfroTropical Region, Madagascar, south-eastern Europe, southern and eastern Asia, the indo-Malayan Region, eastern Australia and Tasmania. They also mentioned that the distribution of this genus extended over much of central and southern Europe during the late Pliocene and Pleistocene. African representatives of the genus Corbicula were separated by Haas (1936) into two groups, one with a smooth ligament plate (4 species), the other with a crenulated ligament plate (1 species). According to Mandahl-Barth (1988) this is incorrect since the ligament plate in all species is more or less uneven. This author is therefore of the opinion that the many species of Corbicula previously described as being from Africa should be included in only 2 species groups, namely the $C$. fluminalis-group and the C. astartina-group, the latter group restricted to Africa. Identification of the Bivalvia in the National Freshwater Snail Collection (NFSC) of South Africa was largely based on the monograph of Connollyi (1939) who acknowledged only 2 species of this genus in South Africa, namely C. africana and C. astartina (Martens 1860). After studies on the freshwater bivalves of Africa, Mandahl-Barth (1988) also came to the conclusion that these were the only 2 species of this genus represented in South Africa, but regarded the previously known C. africana as conspecific with the widespread Asian clam, C. fluminalis and considered it as a defendable subspecies, C. fluminalis africana (Krauss 1848). According to Mandahl-Barth (1988) two other

\footnotetext{
* To whom all correspondence should be addressed.

용 +27 18299 2380; fax: +27 18299 2370;

e-mail: kenne.dekock@nwu.ac.za

Received 21 July 2006; accepted in revised form 19 July 2007.
}

defendable subspecies occur in east and central African lakes, namely C. fluminalis cunningtoni (Smith 1906) in Lake Victoria and C. Aluminalis tanganyicensis (Crosse 1881) in Lake Tanganyika. These are also the subspecies of Corbicula acknowledged by Appleton and Curtis (2007) in their account of the freshwater bivalves of Namibia and Botswana.

This report focuses on the geographical distribution and habitats of $C$. Aluminalis africana as reflected by 390 collection sites currently on record in the database of the NFSC of South Africa. Details of each habitat, as well as mean altitude and mean annual air temperature and rainfall for each locality, were processed to determine chi-square and effect size values.

\section{Methods}

Details of the habitats of all samples of $C$. fluminalis africana that could be located on the on the 1:250 000 topo-cadastral map series of South Africa, dating from 1956 until 2006, were extracted from the database of the NFSC. The number of loci $(1 / 16$ square degrees) in which the collection sites were located, were distributed in intervals of mean annual air temperature and rainfall, as well as intervals of mean altitude to illustrate the frequency of occurrence of this species within specific intervals. Rainfall, temperature and altitude data were made available by the Computing Centre for Water Research in 2001 (disbanded since), University of KwaZulu-Natal. A temperature index was calculated for all mollusc species in the database from their frequencies of occurrence within the selected temperature intervals and the results used to rank them in order of association with low to high climatic temperatures. The method of calculation is discussed in detail in our earlier publications (De Kock and Wolmarans, 2005a; 2005b). Chi-square values were calculated to determine the significance in difference between the frequency of occurrence in, on, or at the different options for each variable, 


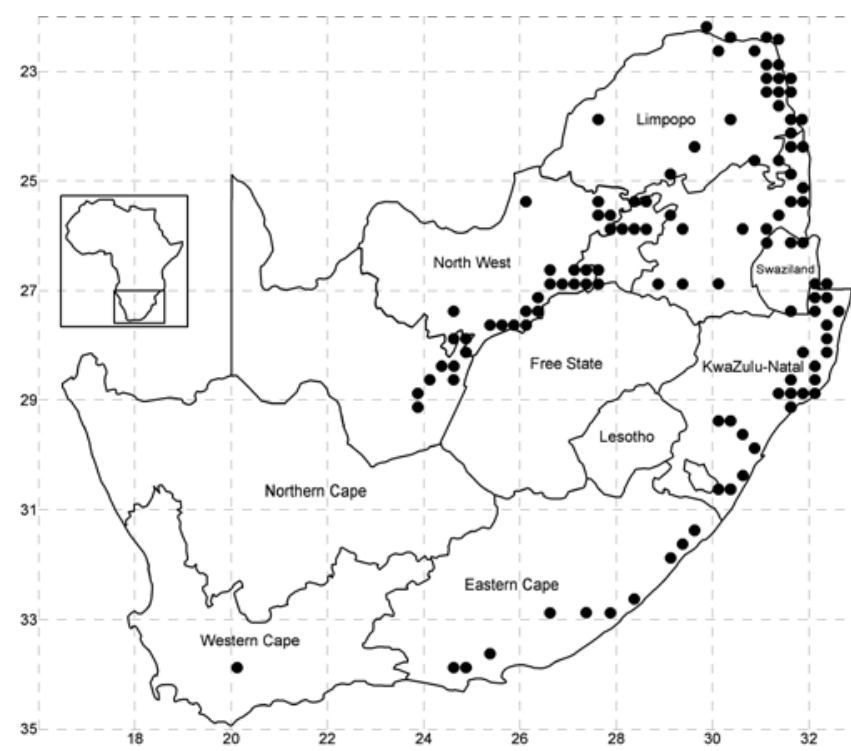

Figure 1

The geographical distribution of Corbicula fluminalis africana s. I. in 1/16 square degree loci in South Africa

such as water-body type, substratum type or temperature interval. In addition an effect size (Cohen, 1977) was calculated for all the different variables discussed in this paper. The effect size is an index which measures the degree of discrepancy between the frequency distribution of a given species in the set of alternatives of a given variable such as water-bodies, as compared to the frequency distribution of all other mollusc species in the database in the set of alternatives of the same variable (Cohen, 1977). According to this author values for this index in the order of 0.1 and 0.3 indicate small and moderate effects respectively, while values in the order of 0.5 and higher indicate practical significant large effects. More details of the significance and interpretation of specific values calculated for this statistic in a given situation, are discussed in our earlier publications (De Kock and Wolmarans, 2005a; 2005b).

\section{TABLE 1}

Water-body types in which Corbicula fluminalis africana s. I. was found in 390 collection sites recorded during surveys

\begin{tabular}{|c|c|c|c|c|}
\hline Water-bodies & $\mathbf{A}$ & B & C & D \\
\hline Channel & 8 & $2.1 \%$ & 169 & $4.7 \%$ \\
\hline Concrete dam & 2 & $0.5 \%$ & 221 & $0.9 \%$ \\
\hline Dam & 40 & $10.3 \%$ & 8400 & $0.5 \%$ \\
\hline Ditch & 5 & $1.3 \%$ & 636 & $0.8 \%$ \\
\hline Irrigation furrow & 2 & $0.5 \%$ & 113 & $1.8 \%$ \\
\hline Pan & 4 & $1.0 \%$ & 306 & $1.3 \%$ \\
\hline Pond & 10 & $2.3 \%$ & 1566 & $0.6 \%$ \\
\hline Quarry & 1 & $0.3 \%$ & 122 & $0.8 \%$ \\
\hline River & 248 & $63.6 \%$ & 7507 & $3.3 \%$ \\
\hline Spring & 1 & $0.3 \%$ & 301 & $0.3 \%$ \\
\hline Stream & 16 & $4.1 \%$ & 7211 & $0.2 \%$ \\
\hline Swamp & 6 & $1.5 \%$ & 2076 & $0.3 \%$ \\
\hline \multicolumn{5}{|c|}{ Effect size: $w=1.09$ (large effect) } \\
\hline \multicolumn{5}{|c|}{$\begin{array}{l}A \text { number of times collected in a specific water-body } \\
B \text { \% of the total number of collections (390) } \\
C \text { Number of times any mollusc was collected in a specific } \\
\text { water-body }\end{array}$} \\
\hline
\end{tabular}

An integrated decision tree (Breiman et al., 1984) was also constructed from the data. This statistical model enables the selection and ranking of those variables that can maximally discriminate between the frequency of occurrence of a given species under specific conditions as compared to all other species in the database. This was accomplished by making use of the SAS Enterprise Miner for Windows NT Release 4.0, April 19, 2000 programme and Decision Tree Modelling Course Notes (Potts, 1999).

\section{Results}

The 113 loci from which the 390 samples of $C$. fluminalis africana were recovered, are depicted in Fig. 1. This species was represented in 12 of the 14 different water-body types on record in the database. Although the largest percentage of samples $(63.3 \%)$ came from rivers, the eight samples from channels represented a higher percentage $(4.7 \%)$ of the total number of times any mollusc in the database was collected from a specific type of water-body (Table 1). The frequency of occurrence in rivers differed significantly $(\mathrm{p}<0.05)$ from all the other types of water-body except from channels $(\chi=1.05, d f=1 ; \mathrm{p}>0.05)$, irrigation furrows $(\chi=3.7, d f=1 ; \mathrm{p}>0.05)$ and pans $(\chi=3.75, d f$ $=1 ; \mathrm{p}>0.05)$. The majority of samples were collected in perennial habitats with clear freshwater but there were relatively small differences with regard to its percentage occurrence in habitats with either fast- flowing, slow-flowing or standing water (Table 2). It should be pointed out, however, that its occurrence in fastflowing water represented a higher percentage $(4.8 \%)$ of the total number of times any mollusc was recovered from habitats with fast-flowing water (Table 2). Its occurrence under these circumstances therefore differed significantly $(p<0.05)$ from the other two possibilities. The majority of samples were collected in habitats with a predominantly sandy substratum (Table 3 ) and its frequency of occurrence on this type of substratum differed significantly $(p<0.05)$ from the other three substrata types on record in the database.

Although the majority of samples (74.6\%) came from sites which fell within the temperature interval ranging from 16 to $20^{\circ} \mathrm{C}$ the 4 samples from sites falling within the 26 to $30^{\circ} \mathrm{C}$ interval represented a much higher percentage $(10.8 \%)$ of the total number of times any mollusc was collected in a locality falling within a specific interval (Table 4). The frequency of occurrence within the 16 to $20^{\circ} \mathrm{C}$ interval therefore differed significantly from the other three intervals (Chi-square values ranging from $\chi=29.4, d f=1 ; \mathrm{p}<0.05$ to $\chi=49.8, d f=1 ; \mathrm{p}<$ 0.05 ). More than $60 \%$ of the samples were collected from sites that fell within the rainfall interval ranging from 601 to $900 \mathrm{~mm} /$ a (Table 4) but no significant differences could be demonstrated between the frequency of occurrence within the 4 rainfall intervals. Although the majority of samples were collected from sites falling within the altitude interval ranging from 1001 to $1500 \mathrm{~m}$ (Table 4), this did not differ significantly from the frequency of occurrence within the interval ranging from 0 to $500 \mathrm{~m}(\chi=2.3$. $d f=1 ; \mathrm{p}>0.05)$.

Effect size values calculated for the various parameters investigated are given in Tables 1 to 4 . The temperature indexes calculated for all mollusc species in the database, as well as their frequencies of occurrence within the selected temperature intervals are displayed in Table 5 and the species are ranked according to their association with cold to high climatic temperatures. From the effect size values listed in Table 5, it can be deduced that $C$. fluminalis africana did not differ significantly in this respect $(w<0.5)$ from 15 of the 53 species on record in the data- 
TABLE 2

Water conditions in the habitats of Corbicula fluminalis africana s. I. as described during surveys

\begin{tabular}{|l|c|c|c|c|c|c|c|c|c|}
\hline & \multicolumn{2}{|c|}{ Type } & \multicolumn{3}{c|}{ Current velocity } & \multicolumn{2}{c|}{ Turbidity } & \multicolumn{2}{c|}{ Salinity } \\
\cline { 2 - 10 } & Perennial & Seasonal & Fast & Slow & Standing & Clear & Muddy & Fresh & Brackish \\
\hline A & 322 & 13 & 106 & 130 & 100 & 261 & 41 & 281 & 2 \\
\hline B & $82.6 \%$ & $3.3 \%$ & $27.2 \%$ & $33.3 \%$ & $25.6 \%$ & $66.9 \%$ & $10.5 \%$ & $72.1 \%$ & $0.5 \%$ \\
\hline C & 22432 & 5350 & 2229 & 9501 & 16147 & 20408 & 6438 & 24089 & 657 \\
\hline D & $1.4 \%$ & $0.2 \%$ & $4.8 \%$ & $1.4 \%$ & $0.6 \%$ & $1.3 \%$ & $0.6 \%$ & $1.16 \%$ & $0.3 \%$ \\
\hline E & \multicolumn{3}{|c|}{$\begin{array}{c}w=0.91 \\
\text { (large effect) }\end{array}$} & \multicolumn{3}{|c|}{0.39} & $\begin{array}{c}w=0.24 \\
\text { (small effect) }\end{array}$ & $\begin{array}{c}w=0.13 \\
\text { (small effect) }\end{array}$ \\
\hline
\end{tabular}

A Number of times collected in a specific water condition

$B \%$ of the total number of collections (390) on record for this species

$C$ Number of times any mollusc was collected in a specific water condition

E Effect size values calculated for each factor

base. The decision tree analysis depicted in Fig. 2 shows that the sites of 250 of the 291 samples of this species falling within the 16 to $20^{\circ} \mathrm{C}$ interval also fell within the altitude interval ranging from 1001 to $1500 \mathrm{~m}$ and that 169 of these samples were recovered from habitats where the current speed was described as either slow or fast running. From Fig. 2 it can also be deduced that 97 of these 169 samples were collected in rivers and channels and that the frequency of occurrence in these two types of water-body differed significantly from the 72 times that it was recovered from the other 10 water-body types.

\section{Discussion}

The genus Corbicula was already represented in the Ethiopian Realm during the Pliocene (Pilsbury and Bequaert, 1927) as mentioned earlier and the first representative of this genus from South Africa, namely C. africana, was described by Krauss (1848) as Cyrena africana from specimens collected in the Gauritz River, Cape Province in 1848. However, as mentioned

\begin{tabular}{|c|c|c|c|c|}
\hline & $\begin{array}{l}\text { abstratum } t \\
\text { nalis afric }\end{array}$ & $\begin{array}{l}\text { TAE } \\
n \text { the } \\
\text { I. as d }\end{array}$ & $\begin{array}{l}\text { ts of } \\
\text { ped d }\end{array}$ & $\begin{array}{l}\text { bicula flumi- } \\
\text { g surveys }\end{array}$ \\
\hline & & Subs & $\mathrm{n}$ types & \\
\hline & Muddy & Stony & Sandy & $\begin{array}{c}\text { Decomposing } \\
\text { material }\end{array}$ \\
\hline $\mathrm{A}$ & 78 & 49 & 176 & 7 \\
\hline $\mathrm{B}$ & $20.0 \%$ & $12.6 \%$ & $45.1 \%$ & $1.8 \%$ \\
\hline $\mathrm{C}$ & 12835 & 7934 & 6523 & 32 \\
\hline $\mathrm{D}$ & $0.6 \%$ & $0.6 \%$ & $2.7 \%$ & $1.1 \%$ \\
\hline E & & & & \\
\hline $\begin{array}{l}A \\
B\end{array}$ & $\begin{array}{l}\text { Number of time } \\
\% \text { of the total } \\
\text { cies } \\
\text { Number of time } \\
\text { specific substro } \\
\% \text { occurrence } \\
\text { water-body wit } \\
\text { Effect size valu }\end{array}$ & $\begin{array}{l}\text { ected on a } \\
\text { er of colle } \\
\text { mollusc } \\
\text { species in } \\
\text { ecific sub } \\
\text { culated fo }\end{array}$ & $\begin{array}{l}\text { fic substr } \\
\text { (390) on } \\
\text { llected in } \\
\text { tal numb } \\
\text { trata }\end{array}$ & $\begin{array}{l}\text { cord for this spe- } \\
\text { vater-body with a } \\
\text { of collections in a }\end{array}$ \\
\hline
\end{tabular}

TABLE 4

Frequency distribution of the 390 collection sites of Corbicula fluminalis africana s. I. in selected intervals of mean annual air temperature and rainfall and mean altitude in South Africa

\begin{tabular}{|c|c|c|c|c|c|c|c|c|c|c|c|c|}
\hline & \multicolumn{4}{|c|}{ Temperature intervals $\left({ }^{\circ} \mathrm{C}\right)$} & \multicolumn{4}{|c|}{ Rainfall intervals (mm) } & \multicolumn{4}{|c|}{ Altitude intervals (m) } \\
\hline & $\begin{array}{c}11- \\
15 \\
\end{array}$ & $\begin{array}{c}16- \\
20 \\
\end{array}$ & $\begin{array}{c}21- \\
25 \\
\end{array}$ & $\begin{array}{c}26- \\
30 \\
\end{array}$ & $\begin{array}{c}0- \\
300\end{array}$ & $\begin{array}{c}301- \\
600 \\
\end{array}$ & $\begin{array}{c}601-- \\
900\end{array}$ & $\begin{array}{l}901- \\
1200 \\
\end{array}$ & $\begin{array}{c}0- \\
500\end{array}$ & $\begin{array}{l}501- \\
1000 \\
\end{array}$ & $\begin{array}{c}1001- \\
1500 \\
\end{array}$ & $\begin{array}{c}1501- \\
2000 \\
\end{array}$ \\
\hline A & 1 & 291 & 94 & 4 & 8 & 128 & 238 & 16 & 100 & 19 & 264 & 7 \\
\hline $\mathrm{B}$ & $0.3 \%$ & $74.6 \%$ & $24.1 \%$ & $1.0 \%$ & $2.1 \%$ & $32.8 \%$ & $61.0 \%$ & $4.1 \%$ & $25.6 \%$ & $4.9 \%$ & $67.7 \%$ & $1.8 \%$ \\
\hline $\mathrm{C}$ & 4758 & 24928 & 4276 & 37 & 975 & 11994 & 19799 & 1203 & 6747 & 4491 & 14918 & 6998 \\
\hline $\mathrm{D}$ & $0.02 \%$ & $1.2 \%$ & $2.2 \%$ & $10.8 \%$ & $0.8 \%$ & $1.1 \%$ & $1.2 \%$ & $1.3 \%$ & $1.5 \%$ & $0.4 \%$ & $1.8 \%$ & $0.1 \%$ \\
\hline $\mathrm{E}$ & \multicolumn{4}{|c|}{$w=0.50$ (large effect) } & \multicolumn{4}{|c|}{$w=0.08$ (small effect) } & \multicolumn{4}{|c|}{$w=0.61$ (large effect) } \\
\hline \multicolumn{13}{|c|}{$\begin{array}{l}\text { A Number of times collected in a locality falling in a specific interval } \\
B \text { \% of the total number of collections (390) on record for this species } \\
C \text { Number of times any mollusc was collected in a locality falling in a specific interval } \\
D \% \text { occurrence of this species in the total number of collections in a specific interval } \\
E \text { Effect size values calculated for each factor }\end{array}$} \\
\hline
\end{tabular}

earlier, after an in-depth study of the African freshwater bivalves, Mandahl-Barth (1988) came to the conclusion that C. africana is conspecific with the Asian clam, C. fluminalis, which is well known as an aggressive invader once introduced, as experienced in countries such as Hungary (Csányi, 1998-99), the New World (Taehwan et al., 2004) and Switzerland (Wittenberg, 2005), amongst others. Another Asian species, C. fluminea (Müller, 1774) which was introduced into North America in 1924 and has since spread throughout the continent, has also been reported from Europe during the past 2 decades (Renard et al., 2000). According to Appleton and Curtis (2007), this species has, to their knowledge, not yet been reported from Africa. However, the possibility that this very successful invader species could already have spread to South Africa cannot be excluded. The identity of the 390 samples discussed in this paper were determined on the strength of shell characteristics exclusively (Connollyi, 1939). Due to a high variation of shell shape, colour and sculpture, identification of different species inside the Corbicula genus could, however, be problematic as pointed out by Sousa et al. (2007a). In an evaluation of the genetic and shell morphological variability of C. fluminea populations from 2 estuaries in Portugal these authors recorded significant differences in shell 
TABLE 5

Frequency distribution in temperature intervals and temperature index of Corbicula fluminalis africana s.I. as compared to all mollusc species in the database of the National Freshwater Snail Collection

\begin{tabular}{|c|c|c|c|c|c|c|c|c|c|c|}
\hline Mollusc species & $\begin{array}{c}\text { Number of } \\
\text { samples }\end{array}$ & $\begin{array}{c}5- \\
10^{\circ} \mathrm{C}\end{array}$ & $\begin{array}{r}11- \\
15^{\circ} \mathrm{C}\end{array}$ & $\begin{array}{r}16- \\
20^{\circ} \mathrm{C}\end{array}$ & $\begin{array}{l}21- \\
25^{\circ} \mathrm{C}\end{array}$ & $\begin{array}{r}26- \\
30^{\circ} \mathrm{C}\end{array}$ & IIndex & ${ }^{2} \mathrm{SD}$ & ${ }^{3} \mathrm{CV}$ & $\begin{array}{c}\text { Effect } \\
\text { size }\end{array}$ \\
\hline Pisidium viridarium & 636 & 201 & 270 & 163 & 2 & & 1.947 & 0.764 & 39.22 & -3.022 \\
\hline Lymnaea truncatula & 723 & 95 & 281 & 343 & 4 & & 2.354 & 0.709 & 30.14 & -2.089 \\
\hline Pisidium casertanum & 5 & & 2 & 3 & & & 2.600 & 0.548 & 21.07 & -1.526 \\
\hline Pisidium langleyanum & 627 & 18 & 173 & 430 & 6 & & 2.676 & 0.544 & 20.33 & -1.352 \\
\hline Pisidium costulosum & 425 & 1 & 138 & 282 & 4 & & 2.680 & 0.492 & 18.34 & -1.343 \\
\hline Bulinus tropicus & 8448 & 32 & 2326 & 5860 & 230 & & 2.744 & 0.502 & 18.31 & -1.196 \\
\hline Gyraulus connollyi & 969 & & 185 & 777 & 7 & & 2.816 & 0.406 & 14.40 & -1.031 \\
\hline Ceratophallus natalensis & 1797 & & 299 & 1430 & 68 & & 2.871 & 0.433 & 15.09 & -0.905 \\
\hline Burnupia (all species) & 2778 & 7 & 287 & 2384 & 100 & & 2.928 & 0.380 & 12.97 & -0.777 \\
\hline Ferrissia (all species) & 540 & & 72 & 420 & 47 & 1 & 2.957 & 0.476 & 16.09 & -0.708 \\
\hline Bulinus reticulatus & 296 & & 6 & 287 & 3 & & 2.990 & 0.174 & 5.83 & -0.634 \\
\hline Assiminea umlaasiana & 2 & & & 2 & & & 3.000 & 0.000 & 0.00 & -0.611 \\
\hline Tomichia cawstoni & 4 & & & 4 & & & 3.000 & 0.000 & 0.00 & -0.611 \\
\hline Tomichia diferens & 10 & & & 10 & & & 3.000 & 0.000 & 0.00 & -0.611 \\
\hline Tomichia lirata & 2 & & & 2 & & & 3.000 & 0.000 & 0.00 & -0.611 \\
\hline Tomichia ventricosa & 89 & & & 89 & & & 3.000 & 0.000 & 0.00 & -0.611 \\
\hline Tomichia tristis & 81 & & & 79 & 2 & & 3.025 & 0.156 & 5.16 & -0.554 \\
\hline Unio caffer & 76 & & 6 & 63 & 6 & 1 & 3.026 & 0.461 & 15.24 & -0.551 \\
\hline Physa acuta & 755 & & & 719 & 36 & & 3.048 & 0.213 & 7.00 & -0.502 \\
\hline Bulinus depressus & 552 & & & 519 & 33 & & 3.060 & 0.237 & 7.76 & -0.474 \\
\hline Arcuatula capensis & 15 & & & 14 & 1 & & 3.067 & 0.258 & 8.42 & -0.458 \\
\hline Lymnaea columella & 2302 & & 81 & 1977 & 243 & 1 & 3.071 & 0.371 & 12.07 & -0.448 \\
\hline Lymnaea natalensis & 4721 & & 205 & 3802 & 713 & 1 & 3.108 & 0.429 & 13.79 & -0.364 \\
\hline Assiminea bifasciata & 17 & & & 15 & 2 & & 3.118 & 0.332 & 10.65 & -0.342 \\
\hline Gyraulus costulatus & 736 & & 20 & 580 & 135 & 1 & 3.159 & 0.437 & 13.84 & -0.247 \\
\hline Bulinus forskalii & 1209 & & 17 & 985 & 204 & 3 & 3.160 & 0.409 & 12.95 & -0.246 \\
\hline Pisidium ovampicum & 6 & & & 5 & 1 & & 3.167 & 0.408 & 12.89 & -0.230 \\
\hline Sphaerium capense & 25 & & 1 & 17 & 7 & & 3.240 & 0.523 & 16.14 & -0.062 \\
\hline Bulinus africanus group & 2930 & & 9 & 2155 & 760 & 6 & 3.260 & 0.450 & 13.82 & -0.015 \\
\hline Corbicula fluminalis africana & 390 & & 1 & 291 & 94 & 4 & 3.267 & 0.437 & 13.38 & 0.000 \\
\hline Tomichia natalensis & 23 & & & 16 & 7 & & 3.304 & 0.470 & 14.24 & 0.085 \\
\hline Thiara amarula & 10 & & & 6 & 4 & & 3.400 & 0.516 & 15.19 & 0.304 \\
\hline Assiminea ovata & 5 & & & 3 & 2 & & 3.400 & 0.548 & 16.11 & 0.304 \\
\hline Melanoides victoriae & 49 & & & 29 & 19 & 1 & 3.429 & 0.540 & 15.75 & 0.370 \\
\hline Biomphalaria pfeifferi & 1639 & & 5 & 880 & 751 & 3 & 3.459 & 0.508 & 14.69 & 0.439 \\
\hline Septaria tesselaria & 2 & & & 1 & 1 & & 3.500 & 0.707 & 20.20 & 0.533 \\
\hline Coelatura framesi & 6 & & & 3 & 3 & & 3.500 & 0.548 & 15.65 & 0.533 \\
\hline Neritina natalensis & 16 & & & 8 & 8 & & 3.500 & 0.516 & 14.75 & 0.533 \\
\hline Bulinus natalensis & 244 & & 2 & 97 & 145 & & 3.588 & 0.510 & 14.20 & 0.734 \\
\hline Segmentorbis planodiscus & 27 & & & 9 & 18 & & 3.667 & 0.480 & 13.10 & 0.915 \\
\hline Segmentorbis angustus & 32 & & & 7 & 25 & & 3.781 & 0.420 & 11.11 & 1.177 \\
\hline Melanoides tuberculata & 305 & & & 64 & 237 & 4 & 3.803 & 0.430 & 11.30 & 1.227 \\
\hline Pisidium pirothi & 23 & & & 4 & 19 & & 3.826 & 0.388 & 10.13 & 1.279 \\
\hline Chambardia wahlbergi & 36 & & & 7 & 28 & 1 & 3.932 & 0.398 & 10.11 & 1.521 \\
\hline Aplexa marmorata & 9 & & & & 9 & & 4.000 & 0.000 & 0.00 & 1.677 \\
\hline Bellamya capillata & 31 & & & & 31 & & 4.000 & 0.000 & 0.00 & 1.677 \\
\hline Eupera ferruginea & 169 & & & 6 & 157 & 6 & 4.000 & 0.267 & 6.68 & 1.677 \\
\hline Lentorbis carringtoni & 8 & & & & 8 & & 4.000 & 0.000 & 0.00 & 1.677 \\
\hline Lentorbis junodi & 12 & & & & 12 & & 4.000 & 0.000 & 0.00 & 1.677 \\
\hline Segmentorbis kanisaensis & 9 & & & & 9 & & 4.000 & 0.000 & 0.00 & 1.677 \\
\hline Chambardia petersi & 39 & & & 1 & 36 & 2 & 4.000 & 0.272 & 6.80 & 1.677 \\
\hline Cleopatra ferruginea & 73 & & & & 71 & 2 & 4.027 & 0.164 & 4.08 & 1.740 \\
\hline Lanistes ovum & 41 & & & & 38 & 3 & 4.073 & 0.264 & 6.47 & 1.845 \\
\hline
\end{tabular}




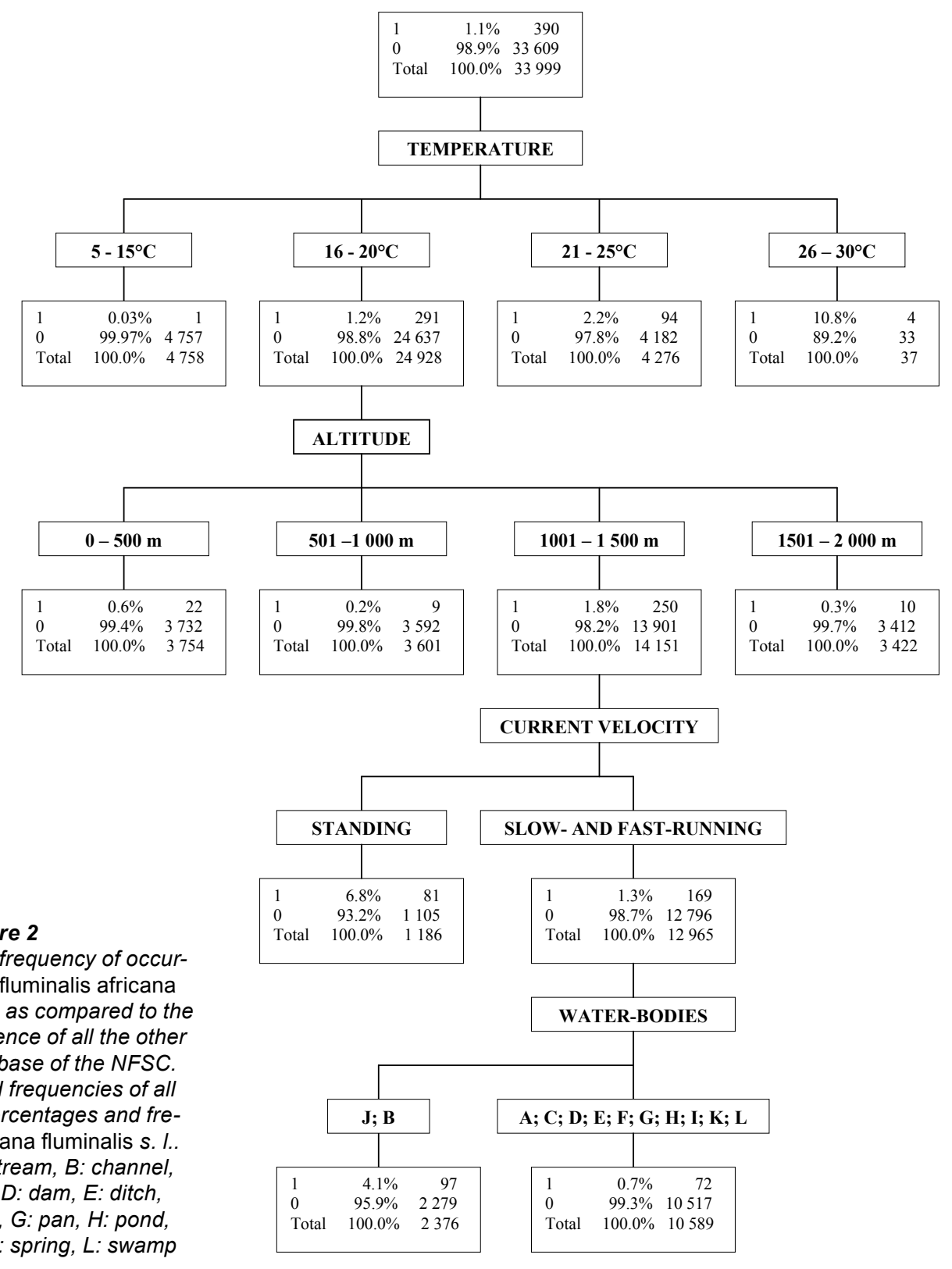

shape between the 2 populations, but identical genetic characteristics. In view of the fact that no genetic criteria were taken into account in the identification of the 390 samples discussed in this paper, these specimens should rather be referred to as C. fluminalis africana sensu lato.

The oldest record of $C$. fluminalis africana s. 1 . in the database of the NFSC dates back to 1956 and was collected in a stream near Groblersdal, Mpumulanga Province. The geographical distribution depicted in Fig. 1 and the habitat preferences presented in Table 1 are largely in accordance with the report by Appleton (2002) that $C$. Aluminalis africana is widespread in rivers, lakes and dams across Southern Africa except for the arid western parts. Although a considerable number of samples of various other freshwater molluscs species are on record in the NFSC for the western parts of South Africa (De Kock et al., 1989; De Kock et al., 2001; De Kock et al., 2002; De Kock and Wolmarans, 2004; De Kock and Wolmarans, 2005c; De Kock and Wolmarans, 2007) the species diversity is significantly lower when compared to the situation in the eastern parts of this country. According to Brown (1978) the obvious explana- tion for this phenomenon is that water in itself is the primary need for an aquatic mollusc and, according to him, there can be no doubt that the more or less arid zone extending from the Western Cape Province through Namibia, Northern Cape Province and Botswana is of overriding importance in that region. It could further be added (Brown, 1978) that there appear to be no endemic molluscs in the specialised fauna living in acid streams in the Western Cape Province (Harrison and Agnew, 1962) or in mountain streams where palaeogenic invertebrates are found (Harrison, 1965). The absence of C. fluminalis africana s. 1. in these parts could therefore most probably be ascribed to the absence of suitable habitats. However, this species could be more widespread than reflected by the distribution in Fig. 1 because specimens can easily be overlooked due to the fact that the species is a bottom dweller. Mandahl-Barth (1988) also mentions that, in his experience, live specimens of Corbicula are not easily obtained since they are sometimes buried in clay at the bottom of a habitat. It should, however, be mentioned that the majority of samples on record in the database of the NFSC has been collected by specially trained staff of the State Ecologist, local 
health authorities and staff of the former Snail Research Unit of the Medical Research Council at Potchefstroom. In the majority of these surveys only sites with lower depth and near the margins of a water-body were surveyed, which might not have been the most appropriate methodology for obtaining specimens of bivalves. However, during seasonal surveys of all available habitat types at 15 sites in the Mooi River (North-West Province) by means of Birge-Ekman grabs, standardised scoops and sediment scrapers designed for quantitative collections of benthic fauna, it was established that the largest populations of the 2 bivalve genera Corbicula and Pisidium were located either on or in sediments in shallow runs near the margins (De Kock and Van Eeden, 1969). From the large number of samples recovered of the gastropod genus Burnupia and of the small bivalve genus Pisidium, as reflected by the data in the database of the NFSC (Table 5), it could be assumed that water-bodies were adequately screened during most of the surveys because these species are not easily found if not specifically searched for.

Corbicula fluminalis africana s. 1. seems not only well adapted to colonise different water-body types as reflected by the results in Table 1, but also has the ability to exploit different habitat types within a specific water-body. In the in-depth study of the habitat selection of the molluscs in the Mooi River by De Kock and Van Eeden (1969), mentioned above, specimens were recovered in all habitat types where sediment samples were taken, such as backwaters, pools, flats, runs and stickles and in some of these habitat types densities of up to $100 / \mathrm{m}^{2}$ were recorded.

In a recent study of abiotic impacts on spatial and temporal distribution of $C$. fluminea in the River Minho estuary in Portugal, it was found that redox potential, nutrient concentrations, hardness, organic matter and sediment characteristics could explain $60 \%$ of the variation in biomass of this species in the freshwater subtidal area (Sousa et al., 2007b). The only abiotic factors reported for the majority of samples on record in the NFSC are those listed in Tables 1 to 4 and to our knowledge no specific data pertaining to the effect of abiotic factors on the biology of the South African species of Corbicula are available in print.

Corbicula fluminalis is well-known for causing severe problems in cooling circuits elsewhere in the world (Rajagopal et al., 1991; Verelst et al., 2005). However, in spite of its relatively wide geographical distribution in the RSA and the fact that it can exploit a variety of habitat types in a wide spectrum of waterbodies, to our knowledge the South African species has not yet been incriminated for causing similar problems in this country.

In studies conducted in a wetland in Iran, it was established that $C$. fluminalis could accumulate heavy metals such as lead, copper, zinc and manganese from superficial sediments (Pourang, 1996). In view of these results, a lifespan ranging between 2 and 7 years reported in literature for $C$. fluminea (Hall, 1984; Marsh, 1985) might be an attribute that could make it a useful candidate for relatively long-term monitoring of heavy metal pollution in selected water-bodies. Although, to our knowledge, no data on the longevity of indigenous South African Corbicula species have yet been reported in literature, Leveque and Saint-Jean (1973) established that $C$. africana had a lifespan of 2 to 3 years and bred seasonally in a lake in Chad. In view of these findings we are of the opinion that the feasibility of exploiting C. fluminalis africana s. 1. as indicator species for monitoring heavy metal pollution in South Africa should be investigated. The facts that this mollusc is fairly widespread in the RSA, and can establish itself in various types of freshwater habitats, especially because of its limited means of locomotion and relatively long lifespan, are attributes which could make it an ideal candidate for such investigations.

\section{Acknowledgements}

The authors wish to thank the following persons and institution: Professors HS Steyn, head of the Statistical Consulting Service and DA de Waal of the Centre for Business Mathematics and Informatics of the North-West University, Potchefstroom Campus for their assistance in processing the data and the NorthWest University for infrastructure and financial support.

\section{References}

APPLETON CC (2002) Mollusca. In: De Moor IJ and Day JA (eds.) Guides to the Freshwater Invertebrates of Southern Africa. Volume 6, Chapter 3: Arachnida \& Mollusca, Araneae, Water Mites \& Mollusca. WRC Report No TT 182/02. Water Research Commission, Pretoria, South Africa. 42-125.

APPLETON CC and CURTIS BA (2007) The freshwater bivalves of Namibia and Botswana. Ann. Eastern Cape Mus. 6 45-71.

BREIMAN L, FRIEDMAN JH, OLSHEN RA and STONE CJ (1984) Classification and Regression Trees. Chapman and Hall.

BROWN DS (1978) Freshwater molluscs: In: Werger MJA (ed.) Biogeography and Ecology of Southern Africa. Junk, The Haque. 11531180 .

COHEN J (1977) Power Analysis for the Behaviour Sciences (revised edn.) Academic Press, Orlando.

CONNOLLY M (1939) A monographic survey of the South African non-marine Mollusca. Ann. S. Afr. Mus. 33 1-660.

CSÁNYI B (1998-99) Spreading invaders along the Danubian highway: first record of Corbicula fluminea (O.F. Müller, 1774) and C. fluminalis (O.F. Müller, 1774) in Hungary (Mollusca: Bivalvia). Fol. Hist. Nat. Mus. Matr. 23 343-345.

DE KOCK KN, JOUBERT PH and PRETORIUS SJ (1989) Geographical distribution and habitat preferences of the invader freshwater snail species Lymnaea columella (Mollusca: Gastropoda) in South Africa. Onderstepoort J. Vet. Res. 56 271-275.

DE KOCK KN and VAN EEDEN JA (1969) Die verspreiding en habitatseleksie van die Mollusca in die Mooirivier, Transvaal. Wetenskaplike Bydraes van die PU vir CHO, Reeks B: Natuurwetenskappe 8 1-119.

DE KOCK KN and WOLMARANS CT (2004) Verspreiding en habitats van Gyraulus connollyi, slaktussengasheer van ingewandsbotte van die familie Echinostomatidae in Suid-Afrika. SA Tydskr. Natuurwet. Teg. 23 79-86.

DE KOCK KN and WOLMARANS CT (2005a) Distribution and habitats of the Bulinus africanus species group, snail intermediate hosts of Schistosoma haematobium and S. mattheei in South Africa. Water SA 31 (1) 117-126.

DE KOCK KN and WOLMARANS CT (2005b) Distribution and habitats of Bulinus depressus and possible role as intermediate host of economically important helminth parasites in South Africa. Water SA 31 (4) 491-496.

DE KOCK KN and WOLMARANS CT (2005c) Distribution, habitats and role as intermediate host of the freshwater snail, Bulinus forskalii, in South Africa. Onderstepoort J. Vet. Res. 72 165-174.

DE KOCK KN and WOLMARANS CT (2007) Verspreiding en habitats van Ceratophallus natalensis (Mollusca: Planorbidae) in SuidAfrika. SA Tydskr. Natuurwet. Teg. 26 109-119.

DE KOCK KN, WOLMARANS CT, BORNMAN M and MAREE DC (2002) Verspreiding en habitats van Bulinus tropicus, tussengasheerslak van die peervormige bot, Calicophoron microbothrium, in Suid-Afrika. SA Tydskr. Natuurwet. Teg. 21 114-120.

DE KOCK KN, WOLMARANS CT, STRAUSS HD and KILLIAN M (2001) Verspreiding en habitats van Lymnaea natalensis, tussengasheerslak van die lewerbot Fasciola gigantica, in Suid-Afrika. SA Tydskr. Natuurwet. Teg. 20 49-53.

HAAS F (1936) Binnen-Mollusken aus Inner-Afrika. Abh. Senckenberg. Naturf. Ges. 431 1-156. 
HALL JJ (1984) Production of immature Corbicula fluminea (Bivalvia: Corbiculidae), in Lake Norman, North Carolina. Nautilus 98 153159.

HARRISON AD (1965) Geographical distribution of riverine invertebrates in southern Africa. Archiv. Hydrobiol. 61 387-394.

HARRISON AD and AGNEW JD (1962) The distribution of invertebrates endemic to acid streams in the Western and Southern Cape province. Ann. Cape Prov. Mus. 2 273-291.

KRAUSS F (1848) Die Südafrikanischen Mollusken. Ein Beitrag zur Kenntniss der Mollusken des Kap- und Natallandes und zur Geographischen Verbreitung derselben, mit Bescreibung und Abbildung der Neuen Arten. Ebner \& Seuber, Stuttgart, Germany.

LEVEVEQUE C and SAINT-JEAN L (1973) Secondary production (zooplankton and benthos). In: Carmouze J-P, Durand J-R and Leveque C (eds.) Monographiae Biologicae. Junk, The Hague. 385-424.

MANDAHL-BARTH G (1988) Studies on African Freshwater Bivalves. Danish Bilharziasis Laboratory, Charlottenlund, Denmark.

MARSH PC (1985) Secondary production of introduced Asiatic clam, Corbicula fluminea, in a central Arizona canal. Hydrobiol. 124 103-110.

PILSBURY HA and BEQUAERT J (1927) The aquatic molluscs of the Belgian Congo, with a geographical and ecological account of Congo malacology. Bull. Amer. Mus. Nat. Hist. 53 69-602.

POTTS WJE (1999) Decision Tree Modeling Course Notes. SAS Institute Inc., Cary, USA.

POURANG N (1996) Heavy metal concentrations in superficial sediments and benthic macroinvertebrates from Anzali wetland, Iran. Hydrobiol. 331 53-61.
RAJAGOPAL S, SASIKUMA N, AZARIA J and NAIR KVK (1991) Some observations on biofouling in the cooling water conduits of a coastal power plant. Biofouling 3 311-324.

RENARD E, BACHMAN V, CARIOU ML and MORETEAU JC (2000) Morphological and Molecular differentiation of invasive freshwater species of the genus Corbicula (Bivalvia, Corbiculidea) suggests the presence of three taxa in French rivers. Molec. Ecol. 9 2009-2016.

SOUSA R, FREIRE R, RUFINO R, MÉNDEZ J, GASPAR M, ANTUNES C and GUILHERMINO L (2007a) Genetic and shell morphological variability of the invasive bivalve Corbicula $\mathrm{Alu}$ minea (Müller, 1774) in two Portuguese estuaries. Est. Coast. Shelf Sci. 74 166-174.

SOUSA R, RUFINO M, GASPAR M, ANTUNES C and GUILHERMINO L (2007b) Abiotic impacts on spatial and temporal distribution of Corbicula fluminea (Müller, 1774) in the River Minho estuary, Portugal. Aquat. Conserv. Mar. Freshw. Ecosyst. 17 1-13.

TAEHWAN L, SIRIPATTRAWAN S, ITUARTE CF and FOIGHIL DO (2004) Invasion of the clonal clams: Corbicula lineages in the New World. Amer. Malac. Bull. 20 113-122.

VERELST L, GIRASA E and DE VRIES T (2005) On-site evaluation of fouling release coatings for the protection of cooling circuits against macro-organisms. http://www.laborelec.com/docs/articles/lbe_art eaux020 uk.pdf (Accessed on 23 February 2006).

WITTENBERG R (2005) Molluscs - Mollusca (Chapter 6). In Wittenberg R (ed.) An Inventory of Alien Species and Their Threat to Biodiversity and Economy in Switzerland. CABI Bioscience Switzerland Centre. Report to the Swiss Agency for Environment, Forest and Landscape. Delémont. 231-247. 
Available on website http://www.wrc.org.za ISSN 0378-4738 = Water SA Vol. 33 No. 5 October 2007 ISSN 1816-7950 = Water SA (on-line) 